Jurnal Konstruksi Hukum | ISSN: XXXX | E-ISSN: XXXX Vol. 1, No. 1, September 2020 Hal. 209-213| Available online at https://www.ejournal.warmadewa.ac.id/index.php/jukonhum DOI: https://doi.org/10.22225/jkh.1.1.2160.209-213

\title{
AKIBAT HUKUM TERHADAP JUAL BELI RUMAH HARTA BERSAMA PASCA PERCERAIAN
}

\author{
Rai Agus Dwi Ernata Putra, I Nyoman Budiartha, Luh Putu Suryani \\ Fakultas Hukum Universitas Warmadewa, Denpasar-Bali, Indonesia
}

\begin{abstract}
Abstrak
Suatu perkawinan di Indonesia merupakan hal yang dianggap sangat-sangat sakral yang dalam masa tersebut tentu menimbulkan adanya akibat yang bervariasi. Seiring dengan masa tersebut tak jarang terjadinya suatu konflik sosial yang menjadi penyakit masyarakat pada saat terjadinya pertengkaran diantara keduanya yakni perceraian yang nantinya tentu akan merembet ke permasalahan lain seperti masalah pengasuhan anak, harta gono-gini dan harta-harta lain yang di dapat semasa perkawinan itu. Adapun tujuan penelitian ini, yaitu mengetahui status terhadap jual beli rumah harta bersama pasca perceraian dan mengetahui akibat hukum terhadap jual beli rumah harta bersama pasca perceraian terhadap pihak ketiga. Penelitian ini menggunakan metode normatif dengan pendekatan undang-undang yaitu dengan cara mengkaji undang-undang, buku dan berbagai pendapat sarjana serta para ahli. Sehingga hasil dari penelitian ini mengungkap bahwa harta kekayaan antara suami dan juga isri telah diatur dan ditetapkan dalam Pasal 119 Kitab Undang Undang Hukum Perdata (KUH Perdata) yang menjelaskan bahwa dimulai dari sah nya suatu perkawinan maka dengan itu pula berlaku persatuan harta secara bulat sepanjang tidak adanya aturan lain yang menyatakan dan mengatur mengenai harta mereka yang terikat perkawinan yang dibuat sebelum pernikahan berlangsung.
\end{abstract}

Kata Kunci: Akibat hukum; Harta bersama; Jual beli rumah; Perceraian

\begin{abstract}
A marriage in Indonesia is a matter that is considered very, very sacred which in that period of course has various consequences. Along with this period, it is not uncommon for a social conflict to become a community disease when a quarrel occurs between the two, namely divorce which will eventually spread to other problems such as childcare issues, gono-gini assets and other assets that were obtained during the marriage. . The purpose of this research is to know the status of the sale and purchase of joint property houses after divorce and to know the legal consequences of buying and selling joint property after divorce against third parties. This study uses a normative method with a statutory approach, namely by reviewing laws, books and various opinions of scholars and experts. So that the results of this study reveal that the assets between the husband and wife have been regulated and stipulated in Article 119 of the Civil Code (KUH Perdata) which explains that starting from the validity of a marriage, it also applies the unanimity of assets as long as it is not There are other rules that state and regulate their assets which are tied to marriage, which were made before the marriage took place.
\end{abstract}

Keywords: Legal consequences; Collective property; Buying and selling of houses; Divorce

\section{PENDAHULUAN}

Dengan lahirnya Undang - Undang No. 1 Tahun 1994 tentang perkawinan yang di telah disahkan pada tangga 12 Januari 1974 lalu diberlakukan secara efektif pada tanggal 1 oktober 1975 ialah salah satu dari bentuk hukum yang ada di Indonesia mengenai perkawinan disertai dengan akibat hukumnya juga. Apabila mengingat tentang ketentuan yang mengatur harta kekayaan suami-istri maka tetap terikat pada perkawinan sesuai aturan tertulis yakni Undang- Undang No.1 Tahun 1974. Terdapatnya Undang-Undang yang mana sifatnya ialah nasionalis tentu saja mutlak harus ada dalam suatu bangsa yang besar sejenis Indonesia yang dimana masyarakat Indonesia tentunya terdiri dari bermacam- macam bahasa suku adat istiadat serta golongan penduduk maka peraturan mengenai perkawinan mengatur berbagai asas tentang hukum perkawinan secara nasional yang tentunya mencakup seluruh prinsip-prinsip perkawinan maka serta juga bisa menjadikan hukum perkawinan yang selama ini dijadikan suatu pegangan yang harus tetap bisa berlaku untuk seluruh golongan di Indonesia (Erwinsyahbana, 2012; Hardani, 2015; Saleh, 1976). Selain diberlakunya Undang-Undang 
tersebut berlaku pula Kitab Undang- Undang Hukum Perdata Hukum Adat serta Hukum Islam. Jadi disini jelas bahwasanya berbagai ketentuan yang mengatur tentang harta benda selama masa perkawinan masih bersifat pluralism hukum (Irianto, 2017; Joeni Arianto Kurniawan, 2012). Hal ini dimungkinkan berlakunya Undang-Undang perkawinan karena terdapat pada Undang Undang tersebut di dalam bab XIV Pasal 66 dengan menyatakan bahwa segala sesuatunya yang memiliki kaitan erat dengan hubungan pernikahan yang berdasarkan atas Undang-Undang Perkawinan maka Kitab Undang-Undang Hukum Perdata (KUH Perdata) Ordonantie perkawinan orang Indonesia yang beragama Kristen yang turut serta dalam mengatur selama hal-hal dalam perkawinan tidak diatur dalam Undang-Undang perkawinan (Aristoni \& Abdullah, 2016). Berdasarkan penjelasan diatas adapun tujuan penelitian ini yaitu mengetahui status terhadap jual beli rumah harta bersama pasca perceraian dan mengetahui akibat hukum terhadap jual beli rumah harta bersama pasca perceraian terhadap pihak ketiga.

\section{METODE PENELITIAN}

Adapun metode penelitian yang digunakan dalam penulisan ini ialah penelitian hukum normatif yang dengan ini dikerjakan dengan mengkaji Undang- Undang terkait masalah serta diterapkan dalam pristiwa hukum tersebut. Sedangkan pendekatan masalah yang digunakan yakni pendekatan peraturan perundang-undangan serta konseptual. Adapun sumber bahan hukum yang digunakan yakni dengan cara di telaahnya seluruh isi undang-undang yang terkait bersama dengan regulasi yang ada sangkut-pautnya mengenai masalah- masalah hukum yang akan dipecahkan oleh penulis. Sedangkan pendekatan konseptual beranjak dari pandangan dan doktrin-doktrin yang berkembang dalam ilmu hukum. Adapun analisis data diolah secara deskriptif analitis yakni dengan mendeskripsikan bahan yang didapatkan dengan berbentuk penjelasan serta uraian - uraian kalimat. Lalu dapat ditarik kesimpulan secara induktif yakni suatu cara berfikir dari hal - hal yang bersifat umum lalu ditarik kesimpulan secara spesifik dan lebih menjurus. Dari kesimpulan-kesimpulan serta data-data dan pernyataan sesuai dengan aturan tertulis yang telah diambil kemudian disampaikan saran - saran serta disajikan secara sistematisasi berupa penulisan karya ilmiah.

\section{HASIL DAN PEMBAHASAN}

\section{Status Rumah Harta Bersama Terhadap Suami Istri Pasca Perceraian dengan Adanya Perjanjian Dan Tidak Adanya Perjanjian}

Pengertian mengenai harta kekayaan secara umum yakni dapat dibedakan menjadi beberapa bagian yaitu

\section{a. Harta Pribadi}

Baik suami maupun istri pada saat menikah memiliki kemungkinan mempunyai harta yang dibawa sebelum menikah (pribadi) maupun harta sendiri yang di dapat setelah menikah. Apabila ikatan yang dimiliki kuat maka barang-barang yang baru didapat tersebut sejak sebelumnya diberikan bagi yang memperoleh serta terhadap barang-barang ini dapat pula diwariskan kepada anak-anak kandung dari pernikahan keduanya.

b. Harta Warisan

Azas yang berlaku secara umum menyatakan bahwa warisan diperoleh dari kerabat sendiri (yang diberikan dalam semasa hidupnya maupun sesudah pewarisnya meninggal) tetaplah milik suami istri dari pewaris tersebut. Harta semacam itu dikatakan sebagai harta pusaka dan atau sering disebut harta asal. Jadi apabila terjadi permasalahan diantara keduanya yang menyebabkan perceraian maka harta tersebut tetaplah mengikuti suami atau istri selaku pemilik semula.

c. Harta Hadiah dalam Upacara Pernikahan

Di beberapa wilayah bagian di Indonesia ada kebiasaan bahwasannya pada saat berlangsungnya suatu pernikahan benda-benda yang nantinya apabila terdapat pembagian harta bersama tersebut maka baik istri taupun suami mendapat bagian yang seimbang atau sama sedang harta benda yang didapatsemasa perkawinan pembagiannya yakni dengan dua berbanding satu (Sudayat, 1978). Persatuan dari harta kekayaan terbatas merupakan perlawanan dari ketentuan Pasal 119 Kitab Undang Undang Hukum Perdata (KUH Perdata) yang mana dalam Pasal tersebut menghendaki adanya persatuan harta kekayaan secara bulat. Penyimpangan ini tetap diperbolehkan oleh Undang- 
undang sepanjang tidak bertentangan dengan Undang-undang kesusilaan yang berlaku serta tidak mengganggu ketertiban umum.

d. Harta Perkawinan Bersama Suami Istri

Disebutkan dalam Pasal 35 ayat 2 Undang Undang perkawinanyang menetapkan bahwasanya harta benda yang didapat semasa perkawinan merupakan harta benda yang nantinya menjadi milik bersama. Adapun harta yang dikatakan harta bersama tersebut dapatmeliputi beberapa hal yakni benda tak bergerak benda bergerak dan juga surat berharga baik yang sudah ada ataupun yang akan ada di suatu hari saat masa perkawinan. Honor penghargaan ataupun hadiah dan sebagainya yang didapat oleh masing- masing pihak yang menimbulkan sebab dari bertambahnya pendapatan yang eratkaitannya dengan pekerjaan ataupun profesi yang dimiliki dan dijalankan sehari-hari oleh suami atau istri menjadi harta yang dimiliki bersama. Sedangkan yang tak berwujud yakni berupa hak atau kewajiban. Keduanya dapat dijadikan jaminan oleh salah satu pihak atas persetujuan dan kesaksian dari pihak lain.

Dengan adanya para pihak menyebabkan penyimpangan dari Undang-undang terhadap harta kekayaan masing-masing yang nantinya menjadi harta bersama. Sehingga persatuan harta kekayaan secara terbatas ini dapat berupa beberapa hal yakni (Harahap, 1986).

1) Persatuan Untung Rugi.

Mengenai hal persatuan untung rugi ini telah dibahas dalam Pasal 115163 dan Pasal 165 Kitab Undang Undang Hukum Perdata (KUH Perdata).

2) Persatuan Hasil dan Pendapatan.

Persatuan hasil dan pendapatan sebagaimana yang telah diatur dalam Pasal 164 Kitab Undang Undang Hukum Perdata yang mengatakan bahwa diantara suami dan istri hanya berlaku oleh keduanya persatuan hasil dari hasil kerja selama pernikahan dan juga persatuan harta kekayaan secara bulat. Dan demikian juga tidak adanya persatuan dari kerugian.

Mengenai timbulnya persatuan harta kekayaan antara suami dan juga isri maka hal-hal tersebut telah diatur dan ditetapkan dalam Pasal 119 Kitab Undang Undang Hukum Perdata (KUH Perdata) yang menjelaskan bahwa dimulai dari sah nya suatu perkawinan maka dengan itu pula berlaku persatuan harta secara bulat sepanjang tidak adanya aturan lain yang menyatakan dan mengatur mengenai harta mereka yang terikat perkawinan yang dibuat sebelum pernikahan berlangsung. Jadi dalam prinsip yang telah menentukan terjadinya persatuan harta kekayaan secara bulat dikarenakan suatu perkawinan ialah apabila tidak ada perjanjian apapun diantara suami dan istri mengenai harta kekayaan. Ini merupakan ketentuan yang sifatnya adalah memaksa sehingga tidak bisa ditentukan waktu yang lain mengenai saat terjadinya persatuan harta kekayaan itu.

Jadi dapat dikatakan bahwa Undang-undang menentukan berbagai cara tentang timbulnya harta kekayaan yang ada pada suami istri dan selain itu Undang-undang juga menghendaki agar selama masa perkawinan keadaan dari harta kekayaan didalam perkawinan itu tetap ada tujuannya untuk melindungi kepentingan pihak ke tiga. Dan juga menetapkan bahwasanya selama masa perkawinan berlangsung persatuan harta kekayaan tersebut maka sebelum sahnya perkawinan tersebut mereka boleh mengadakan perjanjian satu sama lain (Kartohadiprojo, 1988). Apabila ditinjau secara khusus pada Pasal 35 Undang Undang Nomor 1 Tahun 1974 tentang perkawinan mengenai harta bersama yang dalam hal ini merupakan harta benda yang didapat selama masa perkawinan yang lalu menjadi harta benda milik bersama. Sedag mengenai harta bawaan dari para pihak masing-masing sebagai hadiah atau warisan ialah ada pada pengawasan masingmasing pihak sepanjang para pihak tidak menentukan hal tersebut.

Berdasarkan Pasal 35 Undang Undang Nomor 1 Tahun 1974 tentang perkawinan mengenal adanya2 (dua) jenis harta perkawinan pada ikatan suatu kekayaan. Dan kalau kita coba menganalisa harta benda perkawinan yang diatur dalam Pasal 35 Undang Undang perkawinan tersebut seolah-olah menyatakan bahwa harta kekayaan tersebut ditegakkan atas dasar sebagai pondasi untuk mempertahankan adanya kesadaran hukum yang ada di kehidupan masyarakat yakni hukum islam dan juga hukum adat aturan yang telah ditetapkan tersebut tak memiliki orientasi terhadap aturan hukum harta perkawinan secara perdata sebagaimana yang diatur oleh Kitab Undang-undang Hukum Perdata (KUH Perdata) dan juga sebaliknya tidak pula memiliki pertentangan dengan aturan yang telah di modernisasi sebab seperti yang tercantum dalam Pasal 36 Undang Undang Nomor 1 Tahun 1974 tentang perkawinan terhadap harta benda bersama baik suami atau istri dapat bertindak dengan adanya persetujuan diantara kedua belah pihak. 


\section{Akibat Hukum terhadap Jual Beli Rumah Harta Bersama Pasca Perceraian}

Apabila dalam suatu perkawinan sebelum sah sudah dicatatkan oleh keduanya suatu perjanjian kawin yang menyatakan adanya pemisahan semua harta yang dibawa sebelum perkawinan dan juga harta yang diperoleh oleh suami istri (para pihak) itu pada masa pernikahan maka apabila terjadinya perceraia masing-masing dari suami ataupun istri itu hanya memperoleh harta yang telah terdaftar atas nama mereka saja. Karena tidak dikenal istilah harta bersama atau istilah awamnya "harta gono gini". Dengan demikian dalam kasus tersebut sang suami tidak berhak terhadap deviden dari usaha tersebut juga terhadap harta lainnya yang menjadi milik istri begitu juga sebaliknya.

Jika diantara keduanya tidak pernah dicatatkan suatu perjanjian pra-nikah maka sesuai dengan Pasal 119 KUH Perdata dihitung sejak sah nya suatu perkawinan maka harta yang dimiliki adalah harta campuran (jika perkawinan dilakukan sebelum berlakunya Undang Undang Nomor 1 Tahun 1974 tentang Perkawinan). Maka dari itu tentu berakibat harta yang dimiliki istri menjadi harta milik suami juga dan sebaliknya. Inilah yang lalu dikatakan sebagai harta bersama. Terhadap harta bersama apabila keduanya bercerai maka harus dibagi olehnya harta tersebut secara sama rata. Harta bersama tersebut diantaranya segala keuntungan dan juga kerugian yang diperoleh keduanya dari usaha atau juga upaya yang sudah dilakukan oleh keduanya selama mereka masih terikat dalam suatu perkawinan.

Sedikit berbeda dengan pengaturan sebelum berlakunya Undang Undang Nomor 1 Tahun 1974 tentang perkawinan setelah Undang Undang tersebut diberlakukanmengenai harta benda dalam suatu perkawinan sudah diatur dalam Pasal 35 ayat (1) dan juga ayat (2) Undang Undang Nomor 1 Tahun 1974 tentang perkawinan bedanya ialah bagian harta mana yang menjadi harta milik bersama. Dalam Kitab Undang Undang Hukum Perdata (KUH Perdata) seluruh harta yang dimiliki suami dan istri menjadi harta yang dimiliki bersama. Dalam Undang Undang Perkawinan yang dijadikan harta bersama ialah harta benda yang telah diperolehnnya selama perkawinan dan harta-harta yang dimiliki sebelum terjadinya perkawinan yang sah menjadi harta bawaan dari masing-masing pihak baik suami maupun istri. Harta benda dan juga harta bawaan yang diperoleh masing-masing pihak baik suami maupun istri sebagai hadiah keduanya atau warisan ada dalam penguasaan masing-masing pihak sepanjang keduanya tidak menentukan hal lainnya. Maka dari itulah apabila investasi (harta) itu diperoleh dalam masa perkawinan maka telah jadi harta yang dimiliki bersama yang wajib hukumnya untuk dibagi antara suami maupun istri apabila terjadinya perceraian sesuai ketentuan Pasal 37 Undang Undang Nomor 1 Tahun 1974 tentang Perkawinan.

Terhadap penjualan atas rumah yang statusnya adalah harta cempuran gini unsur paling wajib ada ialah terdapatnya suatu kesepakatan diantara keduanya baik suami ataupun istri berkaitan dengan objek yang akan dilakukan jual beli yaitu mengenai harga serta yaitu hak milik atas rumah itu sendiri lalu setelah adanya kesepakatan antara para pihak baik suami/istri dengan pembeli lalu terdapatelah hak serta kewajiban antara para pihak penjual dengan pihak pembeli itu sendiri. Secara yuridis dengan adanya kesepakatan dalam suatu perjanjian jual beli hak milik atas rumah dan harganya itu maka lalu dapatelah dikaitkan dengan ketentuan pasal 1338 KUH Perdata yang dapat menciptakan adanya akibat hukum yang terjadi dari proses tersebut yakni:

a. Perjanjian yang sah berlaku sebagai undang-undang bagi para pihak yang membuatnya.

Karena sifatnya suatu perjanjian dibuat secara sah dihadapan kedua belah pihak bisa berlaku sebagai Undang-undang seperti pengaturan negara bagi mereka yang membuatnya. Sama halnya dengan perjanjian jual beli dengan pemindahan hak milik atas rumah. Di dalam perjanjian jual beli ada sebuah kesepakatan yang telah ditetapkan bersama untuk memberikan hak milik atas rumah dari si penjual kepada si pembeli. Jelas bahwa terdapat pemindahan hak dari penjual ke pembeli atas objek jual- beli tersebut dan apabila berdasarkan dari perjanjian yang telah dibuatnya terdapat suatu perlindungan hukum yang sempurna maka berlakulah diantara mereka sebagai suatu undang-undang. b. Adanya itikad baik antara para pihak penjual dan pembeli

Pada suatu perjanjian jual beli sudah dicantumkan bahwasanya hak milik atas rumah tersebut dijadikan objek jual-beli tidak terdapatpada sebuah sengketa ataupun dalam beban jaminan. Jadi pihak yang menerima pemindahan hak milik atas rumah dimana haknya untuk menguasai dan memiliki objek otomatis telah dijamin kepastian hukumnya sesuai dengan perjanjian tertulis dan juga Undang-Undang yang telah berlaku (Miru, 2007). 
c. Tidak bisa ditarik kembali secara sepihak

dikarenakan perjanjian jual beli adalah perjanjian timbal balik antara para pihak maka diantaranya tidak bisa melakukan pembatalan perjanjian secara sepihak yang diartikan bahwa pemindahan hak milik atas rumah dalam jual beli baru untuk dilakukan pembatalan apabila telah adanya kesepakatan diantara penjual dan juga pembeli. Dengan sebutan lainnya yakni pemindahan dari hak milik atas rumah telah terjamin kepastian hukumnya oleh suatu Per-Undang-undangan.

\section{SIMPULAN DAN SARAN}

\section{Simpulan}

Rumah harta bersama yang telah dijual oleh sepasang suami-istri yang telah melakukakn perceraian tersebut ialah harta bawaan dari masing-masing pihak yang telah menjadi tanggung jawab sendirisendiri. Dan karena pernah menjadi sumai-istri yang sah dimata negara maka harta tersebut bulat dan harus dibagi sama rata diantara keduanya. Sedangkan apabila terjadinya penjualan rumah hasil dari harta mereka maka pihak ketiganya harus tetap membayar lunas rumah yang dibeli sesuai dengan perjanjian kawin yang telah disepakatai si penjual mengenai perjanjian penjualan rumah setelah bercerai. Dan si mantan suami dan antan istripun harus sama-sama sepakat bahwasanya rumah dari harta mereka akan dijual dan hasil penjualannya akan dibagikan rata.

\section{Saran}

Perjanjian kawin sangatlah penting untuk dibuat sebelum melangsungkan suatu perkawinan agar disaat terjadinya suatu konflik di suatu hari maka kepastian hukum dari objek permasalahan jelas cara pemecahannya. Dan sehingga mengenai harta kekayaan jelas serta berkepastian hukum yang tetap. Untuk pemerintah seharusnya ada lex spesialis yang mengatur mengenai pembagian harta suami-istri apabila terjadinya suatu konflik yang menyebabkan perceraian diantara keduanya.

\section{DAFTAR PUSTAKA}

Aristoni, \& Abdullah, J. (2016). 4 Dekade Hukum Perkawinan di Indonesia : Menelisik Problematika Hukum dalam Perkawinan di Era Modernisasi. Yudisia, 7(1).

Erwinsyahbana, T. (2012). Sistem Hukum Perkawinan Pada Negara Hukum Berdasarkan Pancasila. Jurnal Ilmu Hukum Riau, 3(01), 9129.

Harahap, Y. (1986). Segi-segi Hukum Perjanjian. Alumni Bandung.

Hardani, S. (2015). Analisis tentang Batas Umur untuk Melangsungkan Perkawinan menurut Perundang-Undangan di Indonesia. An-Nida': Jurnal Pemikiran Islam, 40(2), 126-139.

Irianto, S. (2017). Sejarah Dan Perkembangan Pemikiran Pluralisme Hukum Dan Konsekuensi Metodologisnya. Jurnal Hukum \& Pembangunan, 33(4), 485.

Joeni Arianto Kurniawan. (2012). Pluralisme Hukum dan Urgensi Kajian Socio-Legal menuju Studi dan Pengembangan

HuJoeni Arianto Kurniawan. 2012. "Pluralisme Hukum Dan Urgensi Kajian Socio-Legal Menuju Studi Dan Pengembangan Hukum Yang Berkeadilan Sosial." Yuridika 27(1):17-34.kum yang Ber. Yuridika, 27(1), 17-34.

Kartohadiprojo, S. (1988). Pengantar Tata Hukum Indonesia Cetakan VI. Sumur Bandung. Miru, A. (2007). Hukum Kontrak dan Perancangan Kontrak PT Raja Grafindo. Persada Jakarta. Saleh, K. W. (1976). Hukum Perkawinan Indonesia cetakan ke IV. Toko Buku Ghalia Indonesia. Sudayat, I. (1978). Hukum Adat. Sketsa Azas Liberty. 